\title{
Amaranth peptides with antithrombotic activity released by simulated gastrointestinal digestion
}

\author{
Ana Clara Sabbione ${ }^{a}$, Agustina Estefanía Nardo ${ }^{b}$, \\ María Cristina Añón ${ }^{a}$, Adriana Scilingo ${ }^{a, *}$ \\ ${ }^{a}$ Centro de Investigación y Desarrollo en Criotecnología de Alimentos (CIDCA), Calle 47 y 116 - 1900, Facultad \\ de Ciencias Exactas, UNLP. CCT La Plata, CONICET (Consejo Nacional de Investigaciones Científica y Técnicas), \\ Argentina \\ ${ }^{b}$ Departamento de Ciencia y Tecnología, Universidad Nacional de Quilmes, Roque Sáenz Peña 182, Bernal. \\ CONICET (Consejo Nacional de Investigaciones Científicas y Técnicas), Argentina
}

\section{A R T I C L E I N F O}

Article history:

Received 15 July 2015

Received in revised form 1 October

2015

Accepted 13 October 2015

Available online

Keywords:

Amaranth protein isolate

Gastrointestinal digestion

Antithrombotic activity

Absorption by Caco 2 cell culture

Bioactive peptides

\begin{abstract}
A B S T R A C T
Amaranth protein isolate was obtained and subjected to simulated gastrointestinal digestion to evaluate its potential antithrombotic activity. The protein isolate did not present fibrin clotting inhibition at the concentrations studied, whereas the hydrolysate ( $\mathrm{DH} \%=51.1 \pm 3.8 \%$ ) exhibited inhibition of fibrin coagulation, showing a dose-response behaviour $\left(\mathrm{IC}_{50}=0.23 \pm 0.02 \mathrm{mg} / \mathrm{mL}\right)$, confirming that the enzymatic treatment was able to release bioactive peptides from amaranth proteins. A fraction with high antithrombotic activity was obtained from this hydrolysate, and resulted to be three times more potent than its original sample $\left(\mathrm{IC}_{50}=0.07 \pm 0.01 \mathrm{mg} / \mathrm{mL}\right.$ ). The absorption of this active fraction was studied with an in vitro peptides transport assay through intestinal epithelium and it was observed that some peptides are able to cross the Caco2-TC7 cell monolayer. Potentially bioactive peptides were found after sequencing them, and informatics tools allowed us to select and locate in their native molecules those peptides prone to inhibit thrombin activity.
\end{abstract}

(c) 2015 Elsevier Ltd. All rights reserved.

\section{Introduction}

Many diseases prevalent in the world nowadays present an important relation with the diet. A healthy diet combined with the intake of functional foods may help minimize or even prevent certain diseases (Jew, AbuMweis, \& Jones, 2009). The functional components can be diverse molecules or microorganisms; among them are bioactive peptides which generally present short sequences and are encrypted in food proteins (Quian, Jung, \& Kim, 2008; Udenigwe \& Aluko, 2012). Over the last decade there have been described different biological activities performed by the bioactive peptides: antimicrobial, antiproliferative, antioxidant, antihypertensive, hypocholesterolaemic, and antithrombotic activity among others (de Castro \& Sato, 2015; Hartmann \& Meisel, 2007). While some of them act on the gastrointestinal system, others require the absorption and transport of peptides into specific sites where they will exercise their action

\footnotetext{
* Corresponding author. CIDCA, Calle 47 y 116 - 1900, La Plata, Argentina. Tel.: +54 221 4249287; fax: +54 2214254853.

E-mail address: aascilingo@gmail.com (A. Scilingo).

Abbreviations: TEER, transepithelial electrical resistance; DH\%, degree of hydrolysis; MTT, methyl tetrazolium assay; AF, active fraction; SEC, size-exclusion chromatography

http://dx.doi.org/10.1016/j.jff.2015.10.015

1756-4646/@ 2015 Elsevier Ltd. All rights reserved.
} 
(Satake et al., 2002). Bioactive peptides could be released from food proteins due to the action of microorganisms' metabolism during fermentation, proteolytic enzymes during food processing or the action of gastrointestinal enzymes once proteins are ingested. An approach to the latter route would be simulated gastrointestinal digestion, a process that promotes the formation of active peptides (Hernández-Ledesma, Amigo, Ramos, \& Recio, 2004) and sometimes increases bioactivity of peptides (Orsini Delgado, Tironi, \& Añón, 2011). This mechanism of peptides production has as an additional advantage on the fact that it checks the stability of the potentially active peptides through the digestive system (Miguel, Aleixandre, Ramos, \& López-Fandiño, 2006). Peptides contained in amaranth seed proteins have shown various biological activities (Barrio \& Añón, 2009; Caselato-Sousa \& Amaya-Farfán, 2012; Fritz, Vecchi, Rinaldi, \& Añón, 2011; Huerta-Ocampo \& Barba de la Rosa, 2011; Mendonça, Saldiva, Cruz, \& Arêas, 2009; Orsini Delgado et al., 2011; Quiroga, Barrio, \& Añón, 2015; Silva-Sánchez et al., 2008; Tiengo, Faria, \& Netto, 2009). The seeds of this Mesoamerican pseudocereal present high percentage of proteins with an excellent amino acid balance (Bale \& Kauffman, 1992). Moreover, amaranth easily adapts to conditions unfavourable for other crops (Paredes-López, 1994).

Antithrombotic peptides inhibit the fibrinogen binding to a specific receptor region on the platelet surface and also inhibit aggregation of platelets. Several antithrombotic peptides derived from food proteins have been described over the last years. Many of them are contained in the milk protein $\kappa$-casein, as they exhibit sequence homologies with fibrinogen chains and bind to a specific receptor region on the platelet surface (Hayes, Stanton, Fitzgerald, \& Ross, 2007). The presence of antithrombotic peptides in other food sources, such as velvet bean, rapeseed and egg white (Segura-Campos, Tovar-Benítez, Chel-Guerrero, \& Betancur-Ancona, 2014; Yang, Wang, \& Xu, 2007; Zhang, Wang, \& Xu, 2008) has also been described. Recently, in vitro antithrombotic activity was observed in amaranth hydrolysates and protein fractions (Sabbione, Scilingo, \& Añón, 2015), but no bioactivity was found in the protein isolate. These amaranth hydrolysates were able to inhibit the thrombin enzyme (EC 3.4.21.5), which is a serine protease that participates at the end of the coagulation cascade and proteolyses fibrinogen to generate fibrin monomers that subsequently polymerize.

The main objectives of this work were to determine if proteins from amaranth manifest antithrombotic activity after subjected to simulated gastrointestinal digestion, and to find those sequences that potentially inhibit thrombin, with the final purpose of using amaranth isolates as functional ingredients.

\section{Materials and methods}

\subsection{Plant material and samples preparation}

\subsubsection{Amaranth seeds}

Amaranthus hypochondriacus (cv Mercado) seeds were harvested in 2011 at Río Cuarto, Córdoba, Argentina.

\subsubsection{Amaranth flour preparation}

Seeds were ground with a cyclone mill ( $1 \mathrm{~mm}$ mesh) and the resulting flour was defatted with $\mathrm{n}$-hexane $(10 \mathrm{~g}$ flour/100 mL n-hexane) during $24 \mathrm{~h}$, the five first hours with constant stirring and then overnight contact.

\subsubsection{Preparation of protein isolates}

Amaranth protein isolate was obtained as described by Martínez and Añón (1996).

\subsubsection{Preparation of hydrolysates}

The method used to simulate gastrointestinal digestion of amaranth isolates was an adaptation of published methods (Hernández-Ledesma et al., 2004; Roesler \& Rao, 2001). The protein isolate was suspended in saline solution $(\mathrm{pH} 2, \mathrm{HCl}$ $0.1 \mathrm{~mol} / \mathrm{L}, 0.03 \mathrm{~mol} / \mathrm{L} \mathrm{NaCl}$ ) and treated with a pepsin solution (0.1 g pepsin/g protein, 1:15,000 5X NF units, MP Biomedicals, Santa Ana, CA, USA) at $37^{\circ} \mathrm{C}$ with agitation during $1 \mathrm{~h}$. Then, $\mathrm{pH}$ was adjusted to 6 and a pancreatin solution was added (0.1 g pancreatin/g protein, 4X-100 USP units/mg, MP Biomedicals, $0.1 \mathrm{~mol} / \mathrm{L} \mathrm{NaHCO}$ ), incubating at $37{ }^{\circ} \mathrm{C}$ with agitation during $1 \mathrm{~h}$. Finally, pancreatin activity was stopped by heating at $85^{\circ} \mathrm{C}$ for $10 \mathrm{~min}$ and suspensions were freeze-dried.

\subsection{Samples characterization}

\subsubsection{Centesimal composition}

Protein content was determined by Kjeldahl, using the conversion factor $5.85 \mathrm{~g}$ protein/g nitrogen (Paredes-López, 1994). Carbohydrates content was determined by the anthrone method (Yemm \& Willis, 1954) after complete acid hydrolysis. Ash content was obtained by heating in a muffle at $550{ }^{\circ} \mathrm{C}$, and water content by drying in a stove at $105^{\circ} \mathrm{C}$ until constant weight is attained (AOAC methods 923.03, and 925.09; 1990). Fibre content was calculated by difference.

\subsubsection{Tricine sodium dodecyl sulphate-polyacrylamide gel} electrophoresis (tricine SDS-PAGE)

Tricine-SDS-PAGE was performed as described by Schägger (2006). Runs were carried out in stacking, spacing and separating gels (160, 100 and $40 \mathrm{~g} / \mathrm{L}$ acrylamide respectively) with 2-mercaptoethanol (2-ME, $50 \mathrm{~mL} / \mathrm{L}$ sample buffer). Two protein molecular mass standards were used: GE Healthcare (Uppsala, Sweden) low molecular standards and Bio-Rad (Hercules, CA, USA) very low molecular standards. Gels were fixed in a methanol-acetic acid solution and stained with Coomassie Brilliant Blue R-250 (Anedra, San Fernando, Argentina) or when necessary, silver staining was applied to increase analytical sensitivity.

\subsubsection{Degree of hydrolysis ( $\mathrm{DH} \%$ )}

Free amino groups were quantified by the o-phthaldialdehyde method (OPA, Sigma, St. Louis, MO, USA) according to Nielsen, Petersen, and Dambmann (2001). To calculate the DH\%, the following expression was used:

$\mathrm{DH} \%=100 \times\left(\mathrm{NH}_{2 \mathrm{t}}-\mathrm{NH}_{2 \mathrm{to}}\right) /\left(\mathrm{NH}_{2+\infty}-\mathrm{NH}_{2 \mathrm{to}}\right)$

$\mathrm{NH}_{2}, \mathrm{NH}_{2}$ to , and $\mathrm{NH}_{2}$ to were the free amino groups at time $t$, initial time (0) and infinite time of hydrolysis, respectively. $\mathrm{NH}_{2}$ to was determined experimentally from an unhydrolysed 
isolate, and $\mathrm{NH}_{2}$ to was obtained using the following expression:

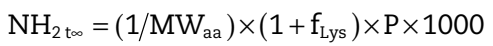

where $\mathrm{MW}_{\mathrm{aa}}$ is the average molecular weight of the amino acids of amaranth proteins, $130 \mathrm{~g} / \mathrm{mol}, \mathrm{f}_{\mathrm{Lys}}$ is the lysine proportion in amaranth proteins, $1 / 16$ (Paredes-López, 1994) and P is the protein concentration.

\subsection{Antithrombotic activity}

\subsubsection{Samples preparation}

Suspensions of the samples in the assay buffer $(50 \mathrm{mmol} / \mathrm{L}$ Tris$\mathrm{HCl}, \mathrm{pH} 7.2,0.12 \mathrm{mmol} / \mathrm{L} \mathrm{NaCl}$ ) were prepared, and incubated for $1 \mathrm{~h}$ at $25^{\circ} \mathrm{C}$ with agitation. Samples were then centrifuged at $10,000 \mathrm{~g}$ for $30 \mathrm{~min}$ at $15^{\circ} \mathrm{C}$. The protein content in the supernatant was determined by the Lowry colorimetric method (Lowry, Rosebrough, Farr, \& Randall, 1951).

\subsubsection{Determination}

Antithrombotic activity was determined with the microplate method informed by Yang et al. (2007). A range of concentrations of each solubilized sample was studied. In a microplate $140 \mu \mathrm{L}$ of $0.1 \mathrm{~g} / 100 \mathrm{~mL}$ fibrinogen (Sigma) were added, $40 \mu \mathrm{L}$ of every sample or buffer as a negative control of the coagulation inhibition or $0.3 \mathrm{mg} / \mathrm{mL}$ heparin (Abbott, Alameda, CA, USA) as a positive control of the coagulation inhibition. The coagulation process was initiated after adding $10 \mu \mathrm{L}$ of thrombin (12 UI/mL, Sigma). Absorbance at $405 \mathrm{~nm}$ was measured in a microplate reader (BioTek Synergy HT, Winooski, VT, USA) before adding the enzyme and after $10 \mathrm{~min}$ incubation at $37^{\circ} \mathrm{C}$. The percentage of inhibition (\% Inhibition) was calculated with the following equation:

\% Inhibition $=100 \times[(C-C B)-(S-S B)] /(C-C B)$

where,

$\begin{array}{ll}\mathrm{CB} \text { (control blank): } & \begin{array}{l}\text { the initial absorbance of the negative control } \\ \text { of inhibition. }\end{array} \\ \mathrm{C} \text { (control): } & \begin{array}{l}\text { the absorbance of the negative control at } \\ 10 \text { min of incubation with thrombin. }\end{array} \\ \text { SB (sample blank): } & \text { the initial absorbance of the sample. } \\ \text { S (sample): } & \begin{array}{l}\text { the absorbance of the sample at } 10 \mathrm{~min} \\ \text { of incubation with thrombin. }\end{array}\end{array}$

\subsection{Obtaining bioactive peptides}

Fractionation of the hydrolysate was performed using sizeexclusion chromatography (SEC) in a Pharmacia LKB, FPLC System, using a molecular exclusion column (GE Healthcare total volume $25 \mathrm{~mL}$ ), Superdex-75 10/300-GL column (range: 3-70 kDa). The column was calibrated with blue dextran (void volume, $\mathrm{Vo}=7.3 \mathrm{~mL})$, albumin $(67 \mathrm{kDa})$, ovalbumin $(44 \mathrm{kDa})$, chymotrypsin $(25 \mathrm{kDa})$, ribonuclease $(19 \mathrm{kDa})$ and aprotinin $(6.5 \mathrm{kDa})$ from GE Healthcare, obtaining the following calibration equation: $\log \mathrm{MW}=-0.1104 \mathrm{Ve}+2.701$

where MW and Ve are molecular weight and elution volume of the resolved species, respectively.

\subsection{Absorption in vitro assay}

\subsubsection{Caco 2 cell culture}

Caco 2-TC7 cells were obtained from American Type Culture Collection (Rockville, MD, USA) and passage numbers between 22 and 30 were used for the formation of the monolayer. Dulbecco's modified Eagle's medium (DMEM) with $4.5 \mathrm{~g} / \mathrm{L}$ glucose, inactivated foetal bovine serum (FBS) and antibiotics (1000 UI penicillin; $1000 \mu \mathrm{g} / \mathrm{mL}$ streptomycin), pH 7.4 was purchased from Microvet SRL (CABA, Argentina) and sterilized with $0.22 \mu \mathrm{m}$ pore size filter (Merck Millipore, CABA, Argentina).

Caco 2-TC7 cells were cultured using techniques described by Yamashita et al. (2000) and Yamashita et al. (2002) at $37{ }^{\circ} \mathrm{C}, 5 \% \mathrm{CO}_{2}$ atmosphere, and $90 \%$ relative humidity. Polycarbonate inserts were seeded (Corning, NY, USA, $0.65 \mathrm{~mm}$ diameter; $0.4 \mu \mathrm{m}$ pores; 24 wells/plate) at a density of $1 \times 10^{5} \mathrm{cells} / \mathrm{cm}^{2}$, to obtain a uniform monolayer. Medium was replaced every $48 \mathrm{~h}$ and the transepithelial electrical resistance (TEER) was measured routinely with a volt ohmmeter equipment (Millicell ERS system, Millipore, Billerica, MA, USA) to analyse the confluence and integrity of the monolayer formed in the inserts. The transepithelial transport activity was determined in apical-basolateral direction using those monolayers that presented TEER values between 450 and 550 ohms.cm² in the inserts, as described by Yamashita et al. (2000, 2002). Fig. 1 shows the inserts and geometry described.

\subsubsection{Peptides transport study}

Caco 2-TC7 were grown in transwell inserts and placed in 24well acrylic plate; phosphate buffered saline (PBS) was added in apical and basolateral chambers $(0.5 \mathrm{~mL})$ and plates were incubated at $37^{\circ} \mathrm{C}, 5 \% \mathrm{CO}_{2}$ and $90 \%$ relative humidity for $20 \mathrm{~min}$. After incubation time PBS was collected and $0.2 \mathrm{~mL}$ of samples were placed in the apical chamber of the inserts, whereas $0.65 \mathrm{~mL}$ of PBS was placed in the basolateral chamber $\left(3 \mathrm{~h}, 37^{\circ} \mathrm{C}\right.$, $5 \% \mathrm{CO}_{2}$ and $90 \%$ relative humidity). Finally, volumes of apical and basolateral chambers were collected for further analysis using RP-HPLC.

Samples used for the transepithelial transport assay were diluted with serum-free DMEM to prepare test solutions.

\subsubsection{Analytical methods}

The content of apical and basolateral chambers $(100 \mu \mathrm{L})$ were analysed with a reversed-phase HPLC system (Waters, Milford, MA, USA), analytical column Sephasil Peptide C8, $12 \mu \mathrm{m}$ ST 4.6/ 250 (Amersham Pharmacia Biotech, Piscataway, NJ, USA). The volume eluted was collected in fractions of $1.1 \mathrm{~mL} /$ tube during the first $60 \mathrm{~min}$ of the chromatographic runs.

\subsubsection{Cytotoxicity}

Methyl tetrazolium assay (MTT, 3-(4,5-dimethylthiazol-2-yl)-2,5diphenyltetrazolium-bromide) was carried out as described by Di Virgilio, Reigosa, Arnal, and Fernández Lorenzo de Mele (2010). 


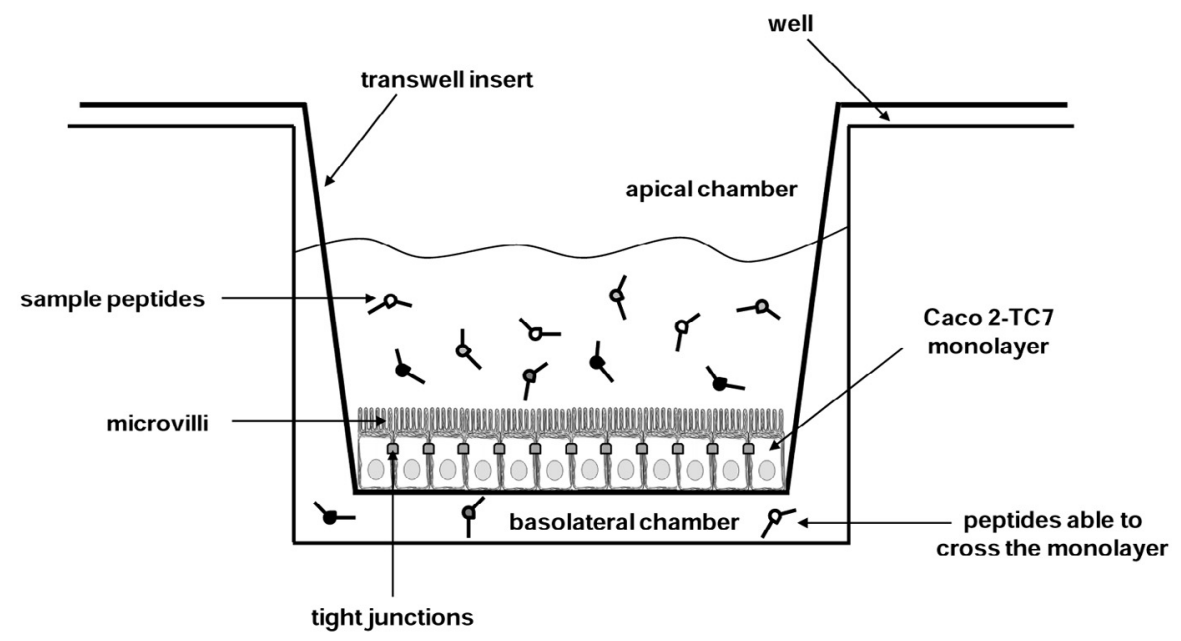

Fig. 1 - Experimental scheme employed to study in vitro absorption of peptides.

Neutral red assay was performed according to Borenfreund and Puerner (1984).

\subsection{Mass spectrometry}

Mass-spectrometry analyses were conducted by the platform "Biopolymers - Structural Biology" located at the INRA Center of Angers-Nantes, France. MALDI-TOF analysis (Micromass/ Waters) was performed to check the sample complexity and estimate the mass of the peptides: $1 \mu \mathrm{L}$ of the sample was mixed with $1 \mu \mathrm{L}$ of the matrix preparation $(2.5 \mathrm{~g} / \mathrm{L} \alpha$-cyano-4hydroxycinnamic acid, $2.5 \mathrm{~g} / \mathrm{L}$ 2,5-dihydroxybenzoic acid, 70\% $\mathrm{v} / \mathrm{v}$ acetonitrile, and $0.1 \% \mathrm{w} / \mathrm{v}$ trifluoroacetic acid) and deposited onto the MALDI sample probe. Many masses below $4000 \mathrm{Da}$ were found; hence an LC-MSMS analysis was performed to get the peptide sequences.

\subsubsection{LC-MS/MS analysis}

Freeze-dried samples were suspended in $0.1 \%$ formic acid in water (solvent A), diluted and analysed by nanoflow liquid chromatography-tandem mass spectrometry (LC-MS/MS). These experiments were performed on an LTQ-Orbitrap VELOS mass spectrometer (Thermo Fisher, Waltham, MA, USA) coupled to a nanoscale liquid-chromatography (LC) system (U3000 RSLC system, Thermo Fisher). Chromatographic separation was conducted on a reverse-phase capillary column (Acclaim PepMap C18, $2 \mu \mathrm{m}$ particle size, $100 \AA$ A pore size, $75 \mu \mathrm{m}$ i.d., $15 \mathrm{~cm}$ length, LC Packings) using a 28 min linear gradient from 4 to $50 \% \mathrm{v} / \mathrm{v}$ $90 \%$ acetonitrile, $0.08 \%$ formic acid (solvent $\mathrm{B}$ ) in solvent $\mathrm{A}$, at a flow rate of $300 \mathrm{~nL} / \mathrm{min}$. Fragmentation of the peptides (MS/ MS) was acquired with full MS scans at 30,000 resolution (FWMH) using the Orbitrap analyser (on a $\mathrm{m} / \mathrm{z}$ range of $300-$ 2000) while the collision-induced dissociation (CID) spectra (MS/ MS) for the five most intense ions were recorded in the linear LTQ trap.

\subsubsection{Protein identification}

Protein identification was achieved by comparing the collected LC-MS/MS data against the Uniprot databank restricted to the Amaranthus taxonomy, using MASCOT Server 2.2 (Matrix
Science, Boston, MA, USA). The parameters used for database searches included: variable oxidation of methionines, and a mass tolerance of $5 \mathrm{ppm}$ for parent ions and $0.5 \mathrm{Da}$ for fragments. Proteins were considered as valid when they were matched with one unique peptide with an individual score above the significance threshold score computed by MASCOT $(\mathrm{p}=0.05)$.

\subsection{Bioinformatic tools}

BIOPEP (http://www.uwm.edu.pl/biochemia/index.php/pl/biopep) was used as the reference database to consult already identified antithrombotic peptides (Minkiewicz, Dziuba, Iwaniak, Dziuba, \& Darewicz, 2008). MEROPS database (http://merops sanger.ac.uk) provided thrombin specificity information (Rawlings, Waller, Barrett, \& Bateman, 2014). ExPASy peptide cutter tool (http://web.expasy.org/peptide_cutter) was used to simulate the proteolysis employed (Gasteiger et al., 2005). Images and analysis of the location of identified peptides in their molecules was performed with The PyMOL Molecular Graphics System, Version 1.7.4 Schrödinger, LLC.

\subsection{Statistical analysis}

Isolates and protein hydrolysates were prepared several times (two at least). Results were evaluated statistically by using variance analysis (ANOVA) with the post-hoc LSD Fisher test $(p=0.05)$.

\section{Results and discussion}

\subsection{Samples characterization}

The per cent composition of the amaranth protein isolate and its hydrolysate was determined (Table 1). The protein percentage of the isolate was similar to values previously informed (Condés, Scilingo, \& Añón, 2009; Orsini Delgado et al., 2011). Fibre content, estimated by difference, doubled the value informed by Condés et al. (2009), probably due to the fact that 
Table 1 - Centesimal composition and degree of hydrolysis (DH\%) of the isolate (I) and hydrolysate obtained after simulation of the gastrointestinal digestion $(\mathbf{H})$.

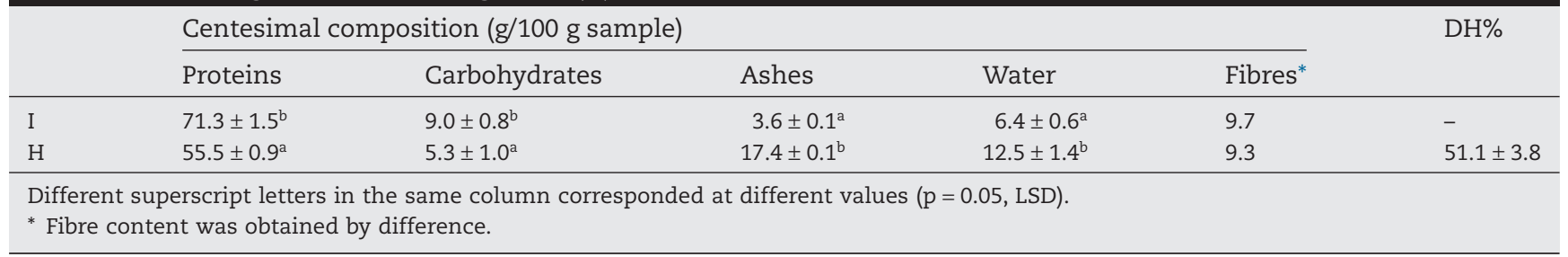

samples in this work were obtained from non-sifted A. hypochondriacus flour. Significant differences are shown in Table 1 between the isolate and its hydrolysate when analysing centesimal composition. Minerals content of the hydrolysate is approximately five times greater than the isolate owing to successive additions of buffers for the simulated gastrointestinal digestion. The hydrolysate retained more water during the lyophilization or it was partially hydrated in the handling due to the higher hydrophilicity of the sample. Degree of hydrolysis ( $\mathrm{DH} \%$ ) of the hydrolysate was $51.1 \pm 3.8 \%$, significantly higher in comparison with the $\mathrm{DH} \%$ reached when hydrolysing amaranth proteins with commercial proteases (Sabbione et al., 2015), indicating that once ingested, the isolate would undergo extensive hydrolysis. Orsini Delgado et al. (2011) obtained a lower DH\%, approximately $40 \%$, using the same digestion protocol.

\subsection{Antithrombotic activity}

In vitro antithrombotic activity of the samples was evaluated with the microplate method in which ability to prevent formation of the fibrin clot is analysed by looking at a diminution or total absence of turbidity. The assay emulates the last stage of blood coagulation, where thrombin hydrolyses fibrinogen generating fibrin monomers that subsequently polymerize. The isolate did not inhibit coagulation at the concentrations studied (0.17 to $12.0 \mathrm{mg}$ protein $/ \mathrm{mL}$ ) coinciding with what informed Sabbione et al. (2015). The hydrolysate exhibited a coagulation inhibition curve vs protein concentration, showing a doseresponse behaviour (Fig. 2a). Inhibitory activity of the hydrolysate was observed at $0.2 \mathrm{mg} / \mathrm{mL}$, and higher concentrations increased the inhibition reaching a plateau at approximately $0.8 \mathrm{mg} / \mathrm{mL}$. These data were processed with the GraphPad Prism program to calculate the IC $_{50}$ of the sample (concentration that inhibits the $50 \%$ of the thrombus formation), which resulted to $0.23 \pm 0.02 \mathrm{mg} / \mathrm{mL}$. This $I_{50}$ value verifies the effectiveness of the digestion to produce peptides with potential antithrombotic activity. Moreover, $\mathrm{IC}_{50}$ values of the hydrolysate resulted lower than those informed for many amaranth protein fractions and its hydrolysates, and slightly higher than glutelin fraction (Sabbione et al., 2015). Other authors informed potential antithrombotic activity of different hydrolysed food proteins. While Shimizu et al. (2009) found that pork peptides could be beneficial in preventing thrombosis, Yang et al. (2007) informed IC 50 values of $50 \mathrm{mg} / \mathrm{mL}$ for egg white peptides, and Zhang et al. (2008) IC $_{50}$ of $30 \mathrm{mg} / \mathrm{mL}$ for rapeseed peptides. The high activity of the hydrolysate could be associated with the degree of hydrolysis reached after performing simulated gastrointestinal digestion, thus, with the presence of small peptides. However, the fact that specific inhibitory peptides are generated cannot be discarded. The potential inhibition of the hydrolysate is a promising result, as the isolate could be the product used as a biologically active food ingredient, and gastrointestinal digestion could be the releasing mechanism of antithrombotic peptides. Moreover, the released peptides are able to resist gastrointestinal digestion. This is a desirable characteristic of bioactive peptides (Korhonen \& Pihlanto-Leppälä, 2001; Picariello et al., 2010).

To separate active compounds of the hydrolysate, a sizeexclusion chromatography was used with a column that separates mass species between 3 and $70 \mathrm{kDa}$. The hydrolysate was solubilized in buffer Tris- $\mathrm{HCl} 0.05 \mathrm{~mol} / \mathrm{L}, \mathrm{NaCl}$ $0.12 \mathrm{mmol} / \mathrm{L}, \mathrm{pH} 7.2$ and eluted with the same solvent. A fraction at elution volume of $14-16 \mathrm{~mL}$ was the only one that presented clot formation inhibition using the microplate method (Fig. 2b). The antithrombotic activity of this active fraction (AF) was studied at different concentrations. Fig. 2c shows the doseresponse inhibition curve obtained as the protein concentration of the sample increases. AF inhibition of the clot formation started at $0.03 \mathrm{mg} / \mathrm{mL}$ protein, and was able to generate a total inhibition at $0.17 \mathrm{mg} / \mathrm{mL}$ protein. The $\mathrm{IC}_{50}$ value was $0.07 \pm 0.01 \mathrm{mg} / \mathrm{mL}$, indicating that $\mathrm{AF}$ is three times more potent than its original sample, the hydrolysate.

Fig. $2 d$ exhibits an electrophoretic Tricine-SDS-PAGE gel. The profile of the A. hypochondriacus isolate was similar to that previously described by Sabbione et al. (2015). The hydrolysate also presents a profile where bands between 26 and $20 \mathrm{kDa}$ stand out and numerous bands under $14.4 \mathrm{kDa}$ appear continuous (Fig. 2d, H). The profile of AF preserves the sharpest band observed in the hydrolysate $(22 \pm 1 \mathrm{kDa})$ with other low molecular weight bands of very low intensity.

\subsection{Absorption in vitro assay: peptides transport study}

To analyse whether peptides content in AF are able to overcome intestinal barriers, an in vitro assay was performed. Peptides were faced with a Caco 2-TC7 epithelial cell monolayer using devices called transwell inserts (Fig. 1). Cytotoxicity tests, MTT and neutral red had to be done to study if AF had an effect on the viability of cells. It was observed that cells preserved $100 \%$ viability in both assays, showing no cytotoxicity effect of the sample over Caco 2-TC7 cells at the concentrations studied (highest concentration: $0.81 \pm 0.03 \mathrm{mg} / \mathrm{mL}$ protein), maintaining total integrity of the monolayers. 
a

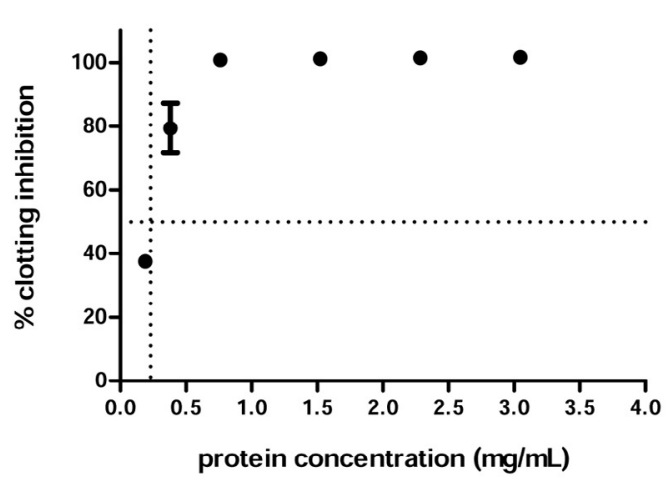

C

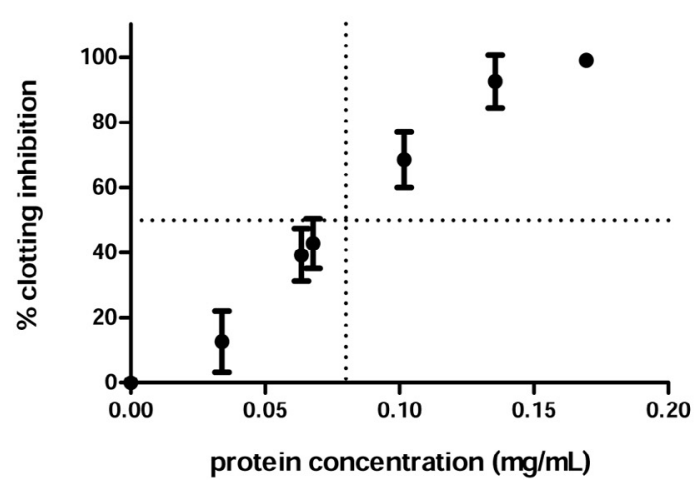

b

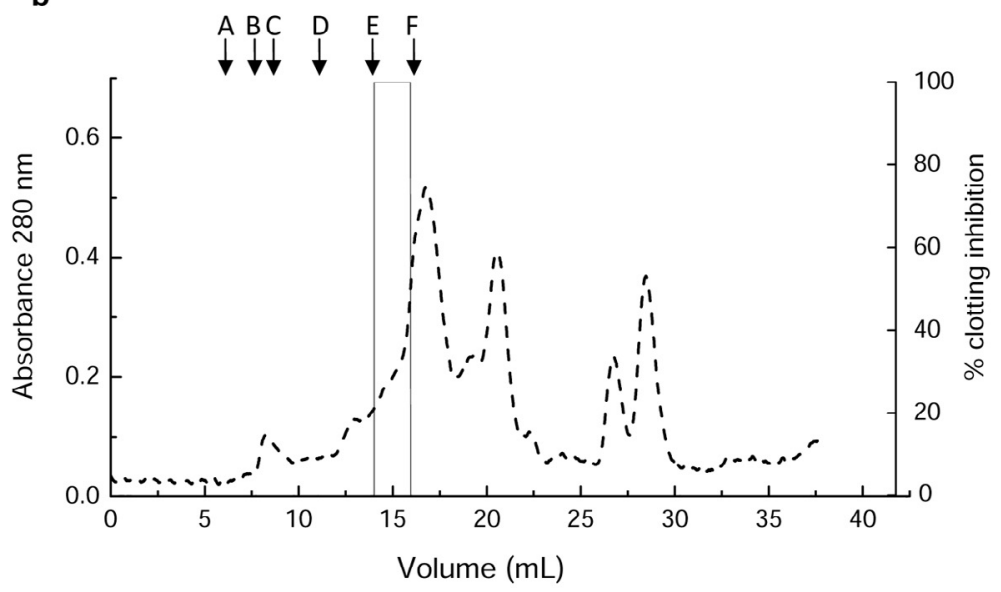

d

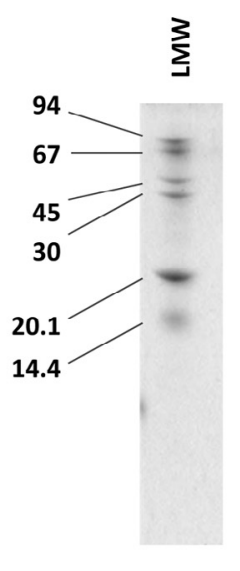

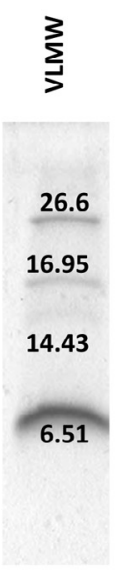

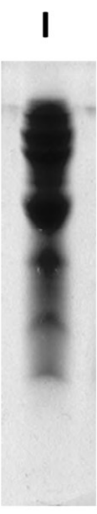

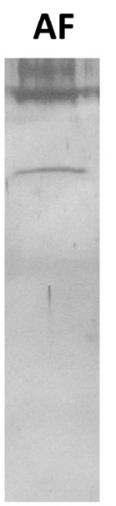

Fig. 2 - (a and c) Percentage of inhibition of thrombus formation vs protein concentration of amaranth hydrolysate (H) and active fraction (AF) respectively. Error bars refer to standard deviation. (b) SEC chromatogram of amaranth hydrolysate (H, --) fractioned using Superdex 75 column (range 3-70 kDa, standard calibration: albumin (B), ovalbumin (C), chymotrypsin (D), ribonuclease (E) and aprotinin (F)). Exclusion volume: blue dextran (A). Per cent clotting inhibition of the fractions collected is exhibited $(-)$. (d) Tricine-SDS-PAGE in reducing conditions. Amaranth isolate (I), hydrolysate (H), and active fraction (AF). LWM and VLMW: low and very low standards molecular weight.

After the absorption in vitro assay of AF, volumes of apical and basolateral chambers were collected from the inserts. Antithrombotic activity of these samples was studied using the microplate method. While AF inhibited completely the clot formation $(0.81 \pm 0.03 \mathrm{mg} / \mathrm{mL}$ protein), the volume of the apical chamber inhibited $91.6 \pm 2.0 \%(0.75 \pm 0.08 \mathrm{mg} / \mathrm{mL}$ protein). The decreased activity of the apical volume after the absorption assay could be associated with the passage of bioactive peptides through the monolayer, in apical-basolateral direction. The antithrombotic activity determined for the basolateral volume was inferior to that obtained for the apical volume, $5.2 \pm 0.5 \%$ (peptide concentration not detected with Lowry method). This result would suggest that some species from AF were able to cross Caco 2-TC7 monolayer and to inhibit coagulation, or that cells released inhibitory compounds to the basolateral chamber. A control assay was performed where PBS was added to the apical chamber instead of the sample. Potential inhibition of coagulation was determined in apical and basolateral volumes, and no sign of activity was detected, discarding our second hypothesis.
It must be taken into consideration that in normal situations, intestinal epithelium has high proteolytic activity. Proteases in the enterocytes complete the proteolytic work initiated in the lumen (Langguth et al., 1997); hence, it is possible that the species found in the apical chamber would get modified inside the cells, generating changes in the initial antithrombotic activity. Even though the experimental strategy was to find the same species contained in the AF, there may be other active species in apical and basolateral chambers.

Reversed-phase chromatography HPLC was used to analyse species contained in apical and basolateral chambers after incubation of AF with the monolayer in the inserts. Samples were filtered and injected in the HPLC equipment. Complementary chromatographies of PBS buffer and AF were performed and a comparative analysis of the chromatograms was made. Three peaks were identified when subtracting peaks of the PBS chromatogram from the peaks of the chromatogram obtained when analysing basolateral sample. These three peaks coincided with those in chromatograms of apical sample and 
AF (not shown results). The tubes that were collected that contained those peaks were lyophilized and analysed.

\subsection{Sequencing and bioactive peptides identification}

Sequences of peptides from AF and basolateral chamber were obtained using MALDI-TOF and liquid nanochromatography with mass spectrometry associated (LC-MS/MS).Results were analysed with MASCOT 2.2 program against Uniprot restricted to Amaranthus taxonomy.

The MALDI mass spectrum of AF was performed. As many masses presented molecular weights below $4000 \mathrm{Da}$, liquid nanochromatography coupled to tandem mass detectors (MS/ MS) was implemented to obtain sequence data. From all the peaks detected, three were identified on the database due to the fact that only few amaranth proteins are sequenced. De novo sequencing was performed to overcome this difficulty, but unreliable results were achieved. The peaks identified in MALDI contained many peptides with sequences belonging to proteins indicated in Table 2. In some cases, various sequences that correspond to the same protein were found, and were pooled in families or groups of sequences that belong to the same region.

Taking into consideration that AF comes from amaranth protein isolate, only sequences found in 11S globulin and agglutinin were analysed, both present in the isolate. Most peptides detected in AF come from $11 \mathrm{~S}$ globulin, sequenced by Molina, Circosta, Añón, and Petruccelli (2008), and agglutinin or lectin, sequenced by Rinderle, Goldstein, Matta, and Ratcliffe (1989). The peptides identified contained in these two proteins were grouped in families (Table 2, Fig. 3). There were

Table 2 - Sequences identified in the active fraction and basolateral chamber of the inserts, by MALDI-TOF, LC-MS/MS, and MASCOT 2.2-Uniprot.

\begin{tabular}{|c|c|c|}
\hline $\begin{array}{l}\text { Protein reported in } \\
\text { 2.2-Uniprot }\end{array}$ & $\begin{array}{l}\text { Sequences } \\
\text { found in } \mathrm{AF}^{\mathrm{a}}\end{array}$ & Families \\
\hline 11S globulin (A. hypochondriacus) & 32 & 9 \\
\hline Agglutinin (A. caudatus) & 11 & 6 \\
\hline Pollen allergen (A. retroflexus) & 8 & 5 \\
\hline Cystatin (A. hypochondriacus) & 2 & 2 \\
\hline $\begin{array}{l}\text { NAD-dependent } \\
\text { malic enzyme (A. hypochondriacus) }\end{array}$ & 2 & 2 \\
\hline $\begin{array}{l}\text { Betaine aldehyde } \\
\text { dehydrogenase (A. hypochondriacus) }\end{array}$ & 1 & 1 \\
\hline \multirow[t]{2}{*}{ NADH dehydrogenase (A. blitoides) } & 1 & 1 \\
\hline & $\begin{array}{l}\text { Sequences } \\
\text { found in } \\
\mathrm{b}-\mathrm{ch}^{\mathrm{b}}\end{array}$ & \\
\hline 11S globulin (A. hypochondriacus) & 2 & 2 \\
\hline Agglutinin (A. caudatus) & 2 & 2 \\
\hline ATP synthase (A. hypochondriacus) & 2 & 2 \\
\hline Malic enzyme (A. hypochondriacus) & 1 & 1 \\
\hline $\begin{array}{l}\text { Trypsin inhibitor } \\
\text { (A. hypochondriacus) }\end{array}$ & 1 & 1 \\
\hline $\begin{array}{l}\text { Soluble starch synthase I } \\
\text { (A. hypochondriacus) }\end{array}$ & 1 & 1 \\
\hline
\end{tabular}

identified 9 families in 11S globulin and 6 families in agglutinin, corresponding to the 24 and $21 \%$ of the respective sequences.

Sequences of the peptides that were able to cross Caco 2-TC7 monolayer were obtained as described previously (Table 2, Fig. 3).

The identified sequences contained in the samples were compared with antithrombotic peptide sequences derived from food proteins. BIOPEP (Minkiewicz et al., 2008) was used as the reference database in which, up to June 5th of 2015, 56 antithrombotic peptides were found. None of them presented matches with the sequences found.

As a first approximation to the action mechanism, and taking into consideration that the microplate method studies the thrombin inhibition produced by the peptides, a database analysis was performed and specific criteria were established to identify those peptides prone to interact with this enzyme.

The criteria used to select potentially active peptides considered the similarity between physiological substrate sequences of thrombin (Huntington, 2005) and our peptides. Thrombin is a serine protease that participates at the end of the coagulation cascade, also known as the common pathway. Regulation of thrombin is performed via a complex mechanism involving, besides the active site, two exosites called I and II. Whereas the active site shows preference for positively charged amino acids, both exosites prefer negatively charged amino acids. While hydrophobic contacts provide the majority of the binding energy for exosite I interactions, they contribute minimally to the overall binding energy for exosite II (Huntington, 2005).

Thrombin interacts preferably with substrata that contain positively charged amino acids in a defined position, called P1 when Schechter and Berger (1967) nomenclature is used. Authors defined amino acids located in the cleavage zone of the peptide bond: $\mathrm{H}_{2} \mathrm{~N}-\mathrm{P} 4-\mathrm{P} 3-\mathrm{P} 2-\mathrm{P} 1-\mathrm{P}^{\prime}-\mathrm{P} 2$ '-P3'-P4'-COOH. The protease cleavage site is indicated with two bold dashes (Huntington, 2005). Even though thrombin presents a complex recognition mechanism, it has been described that the enzyme presents preferences for sequences containing arginine in P1 position, proline in P2 and a hydrophobic residue, which usually is an aromatic amino acid, in P4 (Huntington, 2005; Mehta, Jin, \& Desai, 2013). However, according to MEROPS database information, thrombin specificity (Rawlings et al., 2014) differs to some extent, as in position P4 thrombin interacts preferably with alanine, an aliphatic hydrophobic amino acid.

Parameters that involve characteristics and relative quantities of the amino acids were calculated according to Huntington (2005): net negative charge fraction $\left(f_{n}\right)$ and net hydrophobic fraction $\left(f_{h}\right)$. $f_{n}$ is obtained by subtracting the basic from acidic residues, and dividing by the number of all residues, whereas $f_{h}$ is the ratio of hydrophobic residues divided by the number of all residues. These parameters allowed us to estimate:

Probable interaction of the peptide with active site of the thrombin: the number of positively charged amino acids and their distribution in the sequences was analysed.

Probable interaction of the peptide with exosite $I$ : when $f_{n} / f_{h}$ results $<2$, there is high probability of interaction between the sequence and exosite I. Hydrophobic contacts provide the majority of the binding energy for exosite I interactions, 


\section{I}
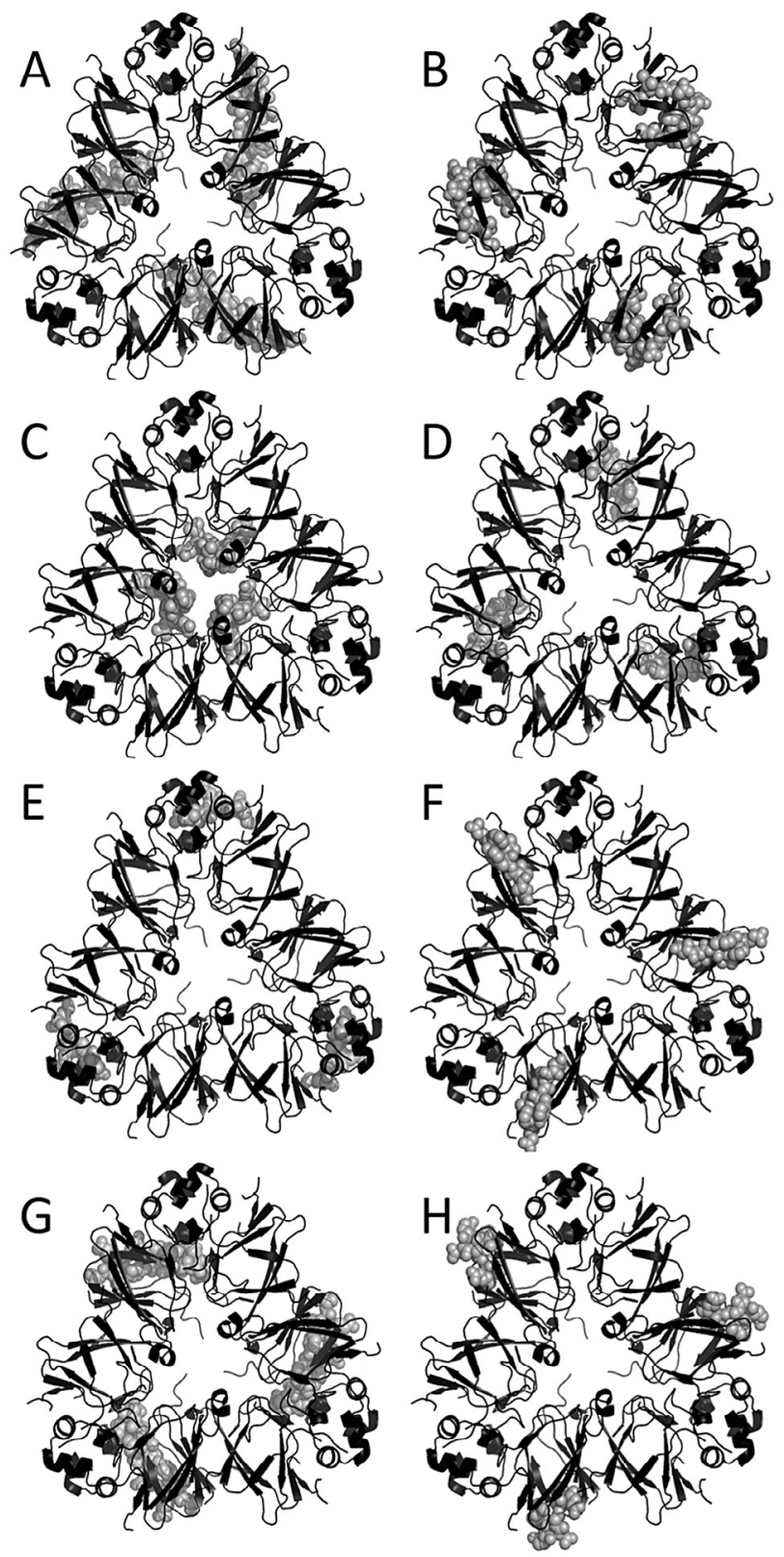

MEGRFREFQQGNECQIDRLTALEPTNRIQAERGLTEVWDSNEQEFRCAGV SVIRRTIEPHGLLLPSFTSAPELIYIEQGNGITGMMI PGCPETYESGSQQ FQGGEDERIREQGSRKFGMRGDRFQDQHQKIRHLREGDIFAMPAGVSHWA YNNGDQPLVAVILIDTANHANQLDKNEPTRFYLAGKPQQEHSGEHQFSRE SRRGERNTGNIFRGFETRLLAESFGVSEEIAQKLQAEQDDRGNIVRVQEG LHVIKPPSRAWEEREQGSRGSRYLPNGVEET ICSARLAVNVDDPSKA DVY TPEAGRLTTVNSFNLPILRHLRLSAAKGVLYRNAMMAPHYNLNAHNIMYC VRGRGRIQIVNDQGQSVFDEELSRGQLVVVPQNFAIVKQAFEDGFEWVSF KTSENAMFQSLAGRTSAIRSLPIDVVSNIYQISREEAFGLKENRPETTLF RSSGQGEYRRKISIA

II

a

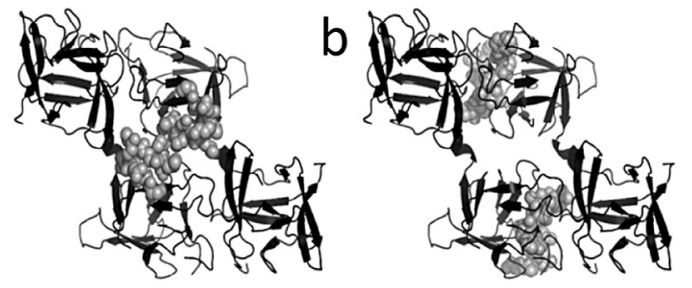

C

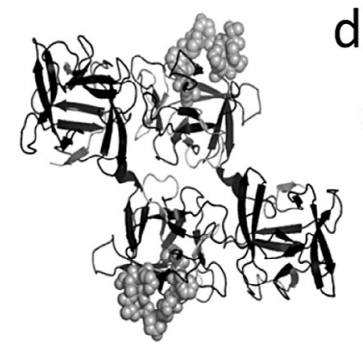

e

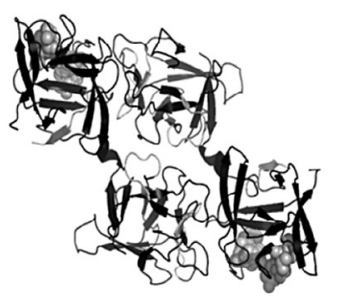

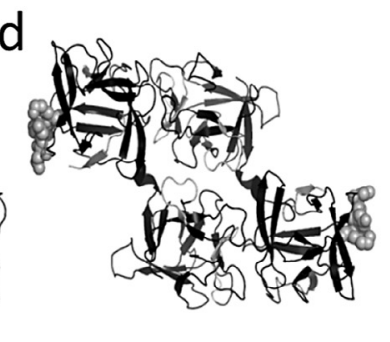

f

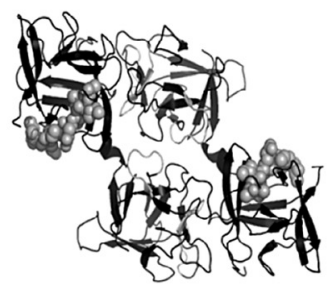

\begin{abstract}
XAGLPVIMCLKSNNHQKYLRYQSDNIQQYGLLQFSADKILDPLAQFEVEP SKTYDGLVHIKSRYTNKYLVRWSPNHYWITASANEPDENKSNSWACTLFKP LYVEEGNMKKVRLLHVQLGHYTQNYTVGGSFVSYLA_ESSQIDTGSRDVF HVIDWKS I FQFPKGYVTFKGNNGKYLGVITI INQLPCLQEFGYNDLNDPKVA HQMFVTSNGT ICIKSNYMNKEWRLSTDDWILVDGNDPRETNEAAALFRSD VHDFNVISLLNMOKTWFIKRETSGKPGFINCMNAATQNVDETAILEIIEL
\end{abstract} GQNN

Fig. 3 - Sequences of potential thrombin inhibitors located in the protein structures and complete sequences of I 11S globulin homotrimer, A. hypochondriacus (UniProt:Q38712) and II agglutinin, Amaranthus caudatus (UniProt:Q71QF2). Grey rectangles indicate families of peptides identified in the active fraction and empty black rectangles show peptides identified in the basolateral chamber. 11S globulin structure is shown in standard orientation (IE side frontwards). The cleavage site where 11S globulin acidic and basic chains are linked is indicated in black. 


\section{Table 3 - Sequences of potentially thrombin inhibitory peptides.}

\begin{tabular}{|c|c|c|c|c|c|c|}
\hline Family & Sequence & \multicolumn{4}{|c|}{ Probable thrombin site of interaction } & Number of amino acids in the sequence \\
\hline \multicolumn{7}{|c|}{ 11S Globulin } \\
\hline & & $\mathrm{f}_{\mathrm{n}}^{\mathrm{b}}$ & $\mathrm{f}_{\mathrm{h}}^{\mathrm{b}}$ & $\mathrm{f}_{\mathrm{n}} / \mathrm{f}_{\mathrm{h}} \mathrm{b}$ & & \\
\hline A & IQAEAGLTEV & 0.2 & 0.2 & 1 & Exosite I & 10 \\
\hline A & TEVWDSNEQE & 0.4 & 0.2 & 2 & Exosite II & 10 \\
\hline C & IDTANHANQLD & 0.09 & 0.09 & 1 & Exosite I & 11 \\
\hline $\mathrm{H}$ & AFEDGFE & 0.43 & 0.29 & 1.5 & Exosite I & 7 \\
\hline G & NDQGQSVFDEELS & 0.31 & 0.15 & 2 & Exosite II & 13 \\
\hline C & IDTANHANQLDK & \multicolumn{4}{|c|}{ Active site } & 12 \\
\hline $\mathrm{D}$ & LAGKPQQEHSGEHQ & \multicolumn{4}{|c|}{ Active site } & 15 \\
\hline $\mathrm{F}$ & DVYTPE & \multicolumn{4}{|c|}{$\mathrm{b}-\mathrm{ch}^{\mathrm{a}}$} & 6 \\
\hline \multicolumn{7}{|c|}{ Agglutinin } \\
\hline $\mathrm{d}$ & DNLNDPK & \multicolumn{4}{|c|}{ Active site } & 7 \\
\hline e & LVDGNDPR & \multicolumn{4}{|c|}{ Active site } & 8 \\
\hline c & AESSQIDTGSK & \multicolumn{4}{|c|}{$\mathrm{b}-\mathrm{ch}^{\mathrm{a}}$} & 11 \\
\hline
\end{tabular}

with electrostatics mostly involved in orienting the complementary hydrophobic surfaces (Myles, Le Bonniec, Betz, \& Stone, 2001).

Probable interaction of the peptide with exosite II: when $f_{n} / f_{h}$ results $\geq 2$, there is high probability of interaction between the sequence and exosite II. Electrostatic interactions are dominant when the peptides establish interactions with this exosite, while hydrophobic ones contribute minimally to the overall binding energy.

Based on the above criteria, sequences presented in Table 3 were identified as potential thrombin inhibitors. Peptides found in the basolateral chamber that were also found in AF were added to this list (Table 3 ) as clotting inhibition was observed when studying this sample. The peptides exhibited will be synthesized to confirm their bioactivity.

After performing an in silico simulation of the proteolysis employed with ExPASy peptide cutter tool (Gasteiger et al., 2005) of 11S globulin and agglutinin molecules, many cleavage sites that released the peptides identified were observed (results not shown). Pepsin (EC 3.4.23.1), trypsin (EC 3.4.21.4) and chymotrypsin (EC 3.4.21.1) were considered as the main proteases involved in this process. Even though there were numerous cleavage sites in the sequences of the proteins that were revealed, the actual proteolytic attack will depend also in the location of these cleavage sites in the quaternary structure of the molecules. Fig. 3 presents the peptides shown in Table 3 located in $11 \mathrm{~S}$ globulin and agglutinin structures. Most of the peptides are positioned in the surface of the molecules, being more exposed to possible proteolytic attacks. In this regard, DVYTPE peptide, found in the basolateral chamber, is located in the IE side of the $11 \mathrm{~S}$ globulin trimer. In the native hexameric molecule, the IE side is bound by non-covalent interactions to the other homotrimer; hence, when the molecule is in its native form, with intact quaternary structure, this peptide would not be exposed (Tandang-Silvas et al., 2012). However, 11S globulin separates by $\mathrm{pH}$ effect ensuring accessibility of proteases to that region of the molecule.

\section{Conclusions}

The amaranth protein isolate obtained did not exhibit clotting inhibition at the concentrations studied. However, the enzymatic treatments performed simulating gastrointestinal digestion were able to generate peptides with potential antithrombotic activity, indicating that this methodology releases bioactive peptides which are encrypted in their native proteins. A fraction with high antithrombotic activity in vitro was obtained from this hydrolysate by size-exclusion chromatography, and resulted three times more potent than its original sample when analysed with the microplate method. The active protein fraction was sequenced and potentially bioactive peptides were found, in particular thrombin inhibitors, one of the possible mechanisms of action that is reflected in the microplate assay. The absorption in vitro assay through intestinal epithelium performed with the active fraction showed that some peptides are able to cross the Caco2-TC7 cell monolayer. After selecting the potentially bioactive peptides, it was observed that most of them are located in the surface of the molecules, being more exposed to proteolytic attacks. Thereby, it must be taken into consideration that an amaranth isolate could be used as a potential functional ingredient with antithrombotic peptides released after ingestion.

\section{Acknowledgements}

The work described was supported by Proyecto de Investigación Plurianual - CONICET (PIP) 11220110101109.

\section{Appendix: Supplementary material}

Supplementary data to this article can be found online at doi:10.1016/j.jff.2015.10.015. 


\section{REFERENCES}

Bale, J. R., \& Kauffman, C. S. (1992). Special issue on grain amaranth. New potential for an old crop. Food Reviews International, 8, 1-4.

Barrio, D. A., \& Añón, M. C. (2009). Potential antitumor properties of a protein isolate obtained from the seeds of Amaranthus mantegazzianus. European Journal of Nutrition, 49, 73-82.

Borenfreund, E., \& Puerner, J. A. (1984). A simple quantitative procedure using monolayer culture for toxicity assays. Journal of Tissue Culture Methods, 9, 7-9.

Caselato-Sousa, V., \& Amaya-Farfán, J. (2012). State of knowledge on amaranth grain: A comprehensive review. Journal of Food Science, 77, 93-104.

Condés, M. C., Scilingo, A., \& Añón, M. C. (2009). Characterization of amaranth proteins modified by trypsin proteolysis. Structural and functional changes. LWT - Food Science and Technology, 42, 963-970.

de Castro, R. J. S., \& Sato, H. H. (2015). Biologically active peptides: Processes for their generation, purification and identification and applications as natural additives in the food and pharmaceutical industries. Food Research International, 74, 185198.

Di Virgilio, A. L., Reigosa, M., Arnal, P. M., \& Fernández Lorenzo de Mele, M. (2010). Comparative study of the cytotoxic and genotoxic effects of titanium oxide and aluminium oxide nanoparticles in Chinese hamster ovary (CHO-K1) cells. Journal of Hazardous Materials, 177, 711-718.

Fritz, M., Vecchi, B., Rinaldi, G., \& Añón, M. C. (2011). Amaranth seed protein hydrolysates have in vivo and in vitro antihypertensive activity. Food Chemistry, 126, 878-884.

Gasteiger, E., Hoogland, C., Gattiker, A., Duvaud, S., Wilkins, M. R., Appel, R. D., \& Bairoch, A. (2005). Protein identification and analysis tools on the ExPASy server. In J. M. Walker (Ed.), The proteomics protocols handbook (pp. 571-607). Totowa: Humana Press.

Hartmann, R., \& Meisel, H. (2007). Food-derived peptides with biological activity: From research to food applications. Current Opinion in Biotechnology, 18, 163-169.

Hayes, M., Stanton, C., Fitzgerald, G. F., \& Ross, R. P. (2007). Putting microbes to work: Dairy fermentation, cell factories and bioactive peptides. Part II: Bioactive peptide functions. Biotechnology Journal, 2, 435-449.

Hernández-Ledesma, B., Amigo, L., Ramos, M., \& Recio, I. (2004). Angiotensin converting enzyme inhibitory activity in commercial fermented products. Formation of peptides under simulated gastrointestinal digestion. Journal of Agricultural and Food Chemistry, 52, 1504-1510.

Huerta-Ocampo, J. A., \& Barba de la Rosa, A. P. (2011). Amaranth: A pseudo-cereal with nutraceutical properties. Current Nutrition and Food Science, 7, 1-9.

Huntington, J. A. (2005). Molecular recognition mechanisms of thrombin. Journal of Thrombosis and Haemostasis, 3, 1861-1872.

Jew, S., AbuMweis, S. S., \& Jones, P. J. H. (2009). Evolution of the human diet: Linking our ancestral diet to modern functional foods as a means of chronic disease prevention. Journal of Medicinal Food, 12, 925-934.

Korhonen, H., \& Pihlanto-Leppälä, A. (2001). Milk protein-derived bioactive peptides. Novel opportunities for health promotion. IDF Bulletin, 363, 17-26.

Langguth, P., Bohner, V., Heizmann, J., Merkle, H. P., Wolffram, S., Amidon, G. L., \& Yamashita, S. (1997). The challenge of proteolytic enzymes in intestinal peptide delivery. Journal of Controlled Release, 46, 39-57.

Lowry, O. H., Rosebrough, N. J., Farr, A. L., \& Randall, R. J. (1951). Protein measurement with the Folin phenol reagent. Journal of Biological Chemistry, 193, 265-275.
Martínez, E. N., \& Añón, M. C. (1996). Composition and structural characterization of amaranth proteins isolates. An electrophoretic and calorimetric study. Journal of Agricultural and Food Chemistry, 44, 2523-2530.

Mehta, A. Y., Jin, Y., \& Desai, U. R. (2013). An update on recent patents on thrombin inhibitors (2010-2013). Expert Opinion on Therapeutic Patents, 24, 1-21.

Mendonça, S., Saldiva, P. H., Cruz, R. J., \& Arêas, J. A. G. (2009). Amaranth protein presents cholesterol-lowering effect. Food Chemistry, 116, 738-742.

Miguel, M., Aleixandre, M. A., Ramos, M., \& López-Fandiño, R. (2006). Effect of simulated gastrointestinal digestion on the antihypertensive properties of ACE-inhibitory peptides derived from ovalbumin. Journal of Agricultural and Food Chemistry, 54, 726-731.

Minkiewicz, P., Dziuba, J., Iwaniak, A., Dziuba, M., \& Darewicz, M. (2008). BIOPEP database and other programs for processing bioactive peptide sequences. Journal of AOAC International, 91, 965-980.

Molina, M. I., Circosta, A., Añón, M. C., \& Petruccelli, S. (2008). Mature Amaranthus hypochondriacus seeds contain non-processed 11S precursors. Phytochemistry, 69, 58-65.

Myles, T., Le Bonniec, B. F., Betz, A., \& Stone, S. R. (2001). Electrostatic steering and ionic tethering in the formation of thrombin-hirudin complexes: The role of the thrombin anionbinding exosite-1. Biochemistry, 40, 4972-4979.

Nielsen, P. M., Petersen, D., \& Dambmann, C. (2001). Improved method for determining food protein degree of hydrolysis. Journal of Food Science, 66, 642-646.

Orsini Delgado, M. C., Tironi, V. A., \& Añón, M. C. (2011). Antioxidant activity of amaranth protein or their hydrolysates under simulated gastrointestinal digestion. LWT - Food Science and Technology, 44, 1752-1760.

Paredes-López, O. (1994). Amaranth: Biology, chemistry and technology. Boca Raton, FL: CRC Press.

Picariello, G., Ferranti, P., Fierro, O., Mamone, G., Caira, S., Di Luccia, A., Monica, S., \& Addeo, F. (2010). Peptides surviving the simulated gastrointestinal digestion of milk proteins: Biological and toxicological implications. Journal of Chromatography B, 878, 295-308.

Quian, Z., Jung, W., \& Kim, S. (2008). Free radical scavenging activity of a novel antioxidative peptide purified from hydrolysate of bullfrog skin, Rana catesbeiana Shaw. Bioresource Technology, 99, 1690-1698.

Quiroga, A. V., Barrio, D. A., \& Añón, M. C. (2015). Amaranth lectin presents potential antitumor properties. LWT - Food Science and Technology, 60, 478-485.

Rawlings, N. D., Waller, M., Barrett, A. J., \& Bateman, A. (2014). MEROPS: The database of proteolytic enzymes, their substrates and inhibitors. Nucleic Acids Research, 42, D503D509.

Rinderle, S. J., Goldstein, I. J., Matta, K. L., \& Ratcliffe, R. M. (1989). Isolation and characterization of amaranthin, a lectin present in the seeds of Amaranthus caudatus, that recognizes the T- (or cryptic T)-antigen. Journal of Biological Chemistry, 264, 1612316131.

Roesler, K. R., \& Rao, A. G. (2001). Rapid gastric fluid digestion and biochemical characterization of engineered proteins enriched in essential amino acids. Journal of Agricultural and Food Chemistry, 4, 3443-3451.

Sabbione, A. C., Scilingo, A., \& Añón, M. C. (2015). Potential antithrombotic activity detected in amaranth proteins and its hydrolysates. LWT - Food Science and Technology, 60, 171177.

Satake, M., Enjoh, M., Nakamura, Y., Takano, T., Kawamura, Y., Arai, S., \& Shimizu, M. (2002). Transepithelial transport of the bioactive tripeptide, Val-Pro-Pro, in human intestinal Caco-2 
cell monolayers. Bioscience, Biotechnology, and Biochemistry, 66, 378-384.

Schägger, H. (2006). Tricine-SDS-PAGE. Nature Protocols, 1, 16-22.

Schechter, I., \& Berger, A. (1967). On the size of the active site in proteases. I. Papain. Biochemical and Biophysical Research Communications, 27, 157-162.

Segura-Campos, M. R., Tovar-Benítez, M., Chel-Guerrero, L., \& Betancur-Ancona, D. (2014). Functional and bioactive properties of Velvet bean (Mucuna pruriens) protein hydrolysates produced by enzymatic treatments. Food Measure, 8, 61-69.

Shimizu, M., Sawashita, N., Morimatsu, F., Ichikawa, J., Taguchi, Y., Ijiri, Y., \& Yamamoto, J. (2009). Antithrombotic papainhydrolyzed peptides isolated from pork meat. Thrombosis Research, 123, 753-757.

Silva-Sánchez, C., Barba de la Rosa, A. P., León-Galván, M. F., De Lumen, B. O., De León-Rodríguez, A., \& González de Mejía, E. (2008). Bioactive peptides in amaranth (Amaranthus hypochondriacus) seed. Journal of Agricultural and Food Chemistry, 56, 1233-1240.

Tandang-Silvas, M. R., Cabanos, C. S., Carrazco Peña, L. D., Barba De La Rosa, A. P., Osuna-Castro, J. A., Utsumi, S., Mikami, B., \& Maruyama, N. (2012). Crystal structure of a major seed storage protein, 11S proglobulin, from Amaranthus hypochondriacus: Insight into its physico-chemical properties. Food Chemistry, 135, 819-826.
Tiengo, A., Faria, M., \& Netto, F. M. (2009). Characterization and ACE-inhibitory activity of amaranth proteins. Journal of Food Science, 74, 121-126.

Udenigwe, C. C., \& Aluko, R. E. (2012). Food protein-derived bioactive peptides: Production, processing, and potential health benefits. Journal of Food Science, 77, 11-24.

Yamashita, S., Furubayashi, T., Kataoka, M., Sakane, T., Sezaki, H., \& Tozuda, H. (2000). Optimized conditions for prediction of intestinal drug permeability using Caco-2 cells. European Journal of Pharmaceutical Sciences, 10, 195-204.

Yamashita, S., Konishi, K., Yamasaki, Y., Taki, Y., Sakane, T., Sezaki, H., \& Furuyama, Y. (2002). New and better protocols for a short-term Caco-2 cell culture system. Journal of Pharmaceutical Sciences, 91, 669-679.

Yang, W. G., Wang, Z., \& Xu, S. Y. (2007). A new method for determination of antithrombotic activity of egg white protein hydrolysate by microplate reader. Chinese Chemical Letters, 18 , 449-451.

Yemm, E. W., \& Willis, A. J. (1954). The estimation of carbohydrates in plant extracts by anthrone. Biochemical Journal, 57, 508-514.

Zhang, S. B., Wang, Z., \& Xu, S. Y. (2008). Antioxidant and antithrombotic activities of rapeseed peptides. Journal of the American Oil Chemists' Society, 85, 521-527. 